\title{
Rethinking Constructive Journalism by Means of Service Journalism
}

From, Unni; Kristensen, Nete Nørgaard

Published in:

Journalism Practice

DOI:

10.1080/17512786.2018.1470475

Publication date:

2018

Document version

Peer reviewed version

Citation for published version (APA):

From, U., \& Kristensen, N. N. (2018). Rethinking Constructive Journalism by Means of Service Journalism. Journalism Practice, 12(6), 714-729. https://doi.org/10.1080/17512786.2018.1470475 
Post-print version

\title{
Rethinking Constructive Journalism by Means of Service Journalism
}

\author{
Unni From \& Nete Nørgaard Kristensen
}

To cite this article: Unni From \& Nete Nørgaard Kristensen (2018): Rethinking Constructive Journalism by Means of Service Journalism, Journalism Practice, DOI: 10.1080/17512786.2018.1470475

To link to this article: https://doi.org/10.1080/17512786.2018.1470475

Published online: 10 May 2018.

\section{RETHINKING CONSTRUCTIVE JOURNALISM BY MEANS OF SERVICE JOURNALISM}

\section{Unni From and Nete Nørgaard Kristensen}

This article argues that constructive journalism scholarship should look to service journalism and its subfields, cultural journalism and lifestyle journalism, to understand the key characteristics of this newer type of journalism. Though constructive journalism is typically associated with the reporting of political and social issues, it is also seen to challenge the traditional ways of writing about such hard news topics due to its positive and solutionoriented approach. In this respect, constructive journalism seems to reuse some of the approaches known from service journalism, especially in terms of audience address and an expanded social role for journalists. However, service journalism emerged in the increasingly commercialized and globalized media landscape of the post-World War II period, whereas constructive journalism has emerged in the digital media landscape of the 2010s. These historical contexts provide particular circumstances for both types of journalism.

KEYWORDS Constructive journalism; cultural journalism; hard news; lifestyle journalism; service journalism; soft news

\section{Introduction}

Constructive journalism is a (normative) concept developed by newsroom practitioners (Gyldensted 2015; Haagerup 2012, 2015, 2017). The predominantly practice-based, non-theoretical literature in the field suggests that news producers should replace their dominating reporting of conflicts with more solution-oriented and guiding stories. Academic research on constructive journalism is limited and often associated with action journalism (Bro 2012), solutions journalism (Benesch 1998; McIntyre 2015, 2017; McIntyre and Gyldensted 2017) and peace journalism (Bläsi 2004; Kempf 2007). As in the last strand of research, and echoing the practice-based literature, constructive journalism research analyses how journalism can provide solutions to conflicts related to the political public sphere. Thus, constructive journalism is typically associated with new approaches in journalism to report important political and social issues, but it is also seen to challenge traditional ways of writing about such hard news topics.

This article provides a different framework for understanding constructive journalism. It makes the case that this type of journalism, in many ways, resembles service journalism (Eide 1992; Eide and 
Knight 1999; Hjarvard 1995) and its subfields, such as journalism on culture, lifestyle and consumption (Hanusch 2012, 2017; Kristensen and From 2012, 2015). Constructive journalism seems to reuse some of the approaches known from these softer types of journalism, e.g. specific genres, the role of the journalist and, especially, a particular way of addressing audiences. The article makes the argument that both service journalism and constructive journalism represent examples of a changed perception of the social role of journalism (Hanitzsch, Löffelholz, and Weaver 2005; Usher 2012) and the increasingly blurred boundaries between hard news and soft news (e.g. Sjøvaag 2015).

Theoretically, the broad field of soft news, more generally, and service journalism, more specifically, have been characterized by a human interest framing and by addressing audiences in their capacity as partly citizens, partly consumers and partly clients (Eide 1992; Eide and Knight 1999). This is an extension of journalism's traditional democratic role of mainly serving citizens. Softer types of journalism have for a long time provided solutions, guidance and reflexivity to the complexity of modern life by taking up cultural phenomena and everyday life issues and by analyzing broader cultural trends and lifestyles (From 2007; Hanusch 2012; 2017; Kristensen and From 2012). Today, both service journalism and constructive journalism seem to aim to empower the individual, provide orientation in a highly complex world and, by doing so, strengthen the collective in modernity (Giddens 1991).

The article proceeds in three main sections: The first section outlines the characteristics of constructive journalism from a practice perspective because constructive journalism has, first and foremost, emerged bottom-up from newsroom practitioners. A main point of departure is the Danish context, as Danish news editors and journalists have been pioneers in pushing constructive news. They have been key in the development of the concept in a newsroom context, nationally and internationally. The second section introduces the scarce academic research in the field-research that, in many ways, resonates with the main principles of the practice-based notion of constructive journalism. Against this backdrop, in the third section, we propose service journalism and its related subfields, such as cultural, lifestyle and consumer journalism, as suitable types of journalism to look to when trying to theoretically grasp the core modes of address of constructive journalism.

By adopting the theoretical frameworks originally developed to understand soft news and service journalism to the area of constructive journalism, the article provides a theoretical contribution to the emerging research field on constructive forms of journalism. First, we show how service journalism may represent an alternative-yet unexplored-perspective on constructive journalism, which provides a stronger focus on audience address and a redefined or expanded social role of journalism. Second, we show that instead of perceiving constructive journalism as a completely new approach, journalism research could look to parts of its own history, which have already laid out a path for journalism similar to the one that constructive journalism aims to pursue. In line with service journalism, constructive journalism can namely be seen as yet another branch of journalism that applies positive approaches to lifeworld issues. Engaging in the study of such types of journalism is important due to their particular characteristics and modes of address, but also because they have achieved less scholarly attention and recognition, as they challenge key values and boundaries of the profession. However, they deserve attention by practitioners as well as by journalism scholars, because they permeate media content and may provide other paths for journalism.

\section{Constructive Journalism in the Making-A Practice Perspective}

Constructive journalism is a relatively new term, developed as an attempt to improve journalism. By its practitioners, it is seen as a potential way out of the crisis of journalism generally, and the crisis of news journalism more specifically, at a time when digital media technologies have made 
immediacy, breaking news and conflict dominant features of journalism (Haagerup 2017). The definition of the concept in the practice-based literature is somewhat vague, as it remains unclear if constructive journalism is a new news criteria or "a mindset to supplement the traditional criteria for news" (Haagerup 2015, 20, 49). In the following, we outline the practice-based literature to see how this literature combines elements from different journalistic approaches and conceptualizations of journalism.

Danish newsrooms have been pioneers in the field of constructive journalism. Especially editor and journalist Ulrik Haagerup and journalist Cathrine Gyldensted have been leading figures. Ulrik Haagerup has authored and edited a number of publications with the purpose of outlining and explaining the aim of constructive journalism. He originally introduced the concept in a newspaper column in 2008 in which he argued that, broadly speaking, journalists are too focused on conflicts and disasters. Even if they include human interest cases to provide identification and bring distant events and topics closer to the lifeworld of citizens, or audiences, they rarely provide inspiration or solutions (Haagerup 2008). The newspaper column was published in the national broadsheet Politiken, the most circulated Danish newspaper, and it caused some debate, especially among his peers from other news media. Among others, Lisbeth Knudsen, at the time CEO and editor-in-chief of the national newspaper Berlingske, and Michael Dyrbye, at the time executive director of news at the second-largest Danish broadcasting company TV 2/Denmark, expressed concern. Both were skeptical towards the term "constructive news". Lisbeth Knudsen (in Andreassen 2010, translation by authors), for example, commented:

When I hear the word constructive journalism, it seems as if this is an attempt to grab reality with a tool and create it in a very specific way, where reality must not be too dangerous or unpleasant. We must not twist reality, if it is ugly. It becomes too artificial for me.

In 2012, Haagerup followed up the column by editing and contributing to the Danish-language anthology Konstruktive nyheder (Constructive news) (Haagerup 2012), which also included entries by politicians, business people, scholars and journalists. A common focus in this also mainly practice-based publication was the diagnosis that the relation between politicians/politics as an institution and journalists/the news media as an institution is unproductive and often results in a general lack of public trust in both politicians and journalists. The underlying argument is that reporting of news is too negative, too focused on conflicts and too tabloid. Accordingly, most of the essays are based on the idea that constructive journalism may potentially be a (positive) renewal of journalism practice, a "third way" (Bro 2012), attempting to rethink journalism from within.

Journalist Cathrine Gyldensted has also written practice-based books about constructive journalism, one of these co-edited by a journalist and teacher at the Danish School of Media and Journalism, Malene Bjerre (Gyldensted and Bjerre 2014; Gyldensted 2015). Moreover, Gyldensted has contributed with a more research-based approach to constructive journalism (2011; McIntyre and Gyldensted 2017). Her main claim resembles that of Haagerup, though emphasizing the effects of constructive news, as she argues that journalism should acknowledge and identify problems and conflicts in society, but also investigate and provide solutions in a positive way (Gyldensted 2015, 7).

Both Gyldensted and Haagerup provide practical advice for journalists on "new" ways of doing journalism. Building her argument on positive psychology, Gyldensted advises journalists to (1) expand the mind, (2) storm the brain, (3) change the question, (4) tell it right and (5) move the world. Theses advices take their point of departure in the potential positive effects on audiences, when news stories are framed in constructive ways. Haagerup's work is based on his experiences as a journalist and news editor and on his reflections about how journalism in its current state does not fulfill its democratic role $(2015,2017)$. Building on the work of futurist Anne Skare Nielsen, he 
argues that key terms, such as originality, intimacy, care, consideration, trust and time, all apply to constructive journalism (Haagerup 2017, 66ff). More specifically Haagerup encourages journalists to build news stories on:

- Originality — let's make it unique;

- Intimacy - let's make it up close, whether in a geographical or emotional sense;

- Care - let's make our stories take care of people and society;

- Consideration - let's make our stories provide understanding, knowledge and perspective;

- Trust — let's be authoritative and believable; Time — let's help others make decisions. Let's prioritize and focus on people's need and not think that our job is to give them more, but to clean up the mess (Haagerup 2017, 67).

Both Gyldensted's and Haagerup's lists points to a new social role for journalism.1 Following Haagerup's keywords, constructive news must provide new ideas, new solutions, new practices and new knowledge to existing problems in culture and society (Haagerup 2015, 57). In this respect, constructive journalism shares traits with the American tradition of "solutions journalism". Solutions journalism was introduced as a journalistic practice in the late 1990s, focusing, much like constructive journalism, on how journalism should not simply pinpoint problems but also provide alternative perspectives and solutions. In an early contribution, Susan Benesch (1998) argues that solutions journalism "differs from other good journalism in one simple way: Instead of pointing out what's wrong in the hope that someone will fix it, solution journalism points out what is right, hoping that someone can imitate it" (Benesch 1998, 39). Both solutions journalism and constructive journalism seem to focus on and connect to hard news topics (Reinemann et al. 2011) because they typically concern political challenges, conflicts and social problems, as also indicated by Benesch literature often relate to the political public sphere and the (declining) empowerment of citizens with suggestions to how constructive news can enable better public debate. Haagerup, for example, points to a foreign corre- spondent facilitating a conversation between fighting groups in Egypt, challenging "them to listen to each other and come up with a compromise for a future in Egypt in which they could all see themselves" $(2015,91)$. He also highlights the television news magazine/show Penge (Money), produced by the Danish public service broadcaster DR. The news magazine advises young people on how to avoid financial debt by "helping people to cut down their expenditure and to put together a realistic plan which others in the same situation could learn from" (Haagerup 2015, 65). It illustrates how journalism, to the benefit of the individual but also of society, helps individuals to sort out financial challenges and in this manner implicitly educates them to become responsible consu- mer-citizens in everyday life. Another example from DR, provided by Gyldensted (2015), is a news story on climate change, focusing on a solution to accumulated toxins in fish. The story investigates how a hormone-disrupting substance, developed by a Norwegian researcher, could be a solution, and it shows how the journalist followed up on political decisions made on the issue (Gyldensted 2015, 116).

Thus, implicitly the practice-based literature links to the normative (Western) percep- tions of journalists' societal role, which scholars have debated for a long time. From this nor- mative perspective, journalism, as phrased by Strömbäck $(2005,332)$, fulfills its social contract with democracy by

providing citizens with the information they need in order to be free and self-governing, the government with the information it needs in order to make decisions in the common interest sensitive to public sentiments, an arena for public discussion, and by acting as a watchdog against abuse of power in politics and other parts of society.

At the same time, constructive journalism connotes an understanding of journalism carry- ing out the role not only of disseminator of news and critical watchdog but also of a positive mediator with 
dedicated journalists engaged in the solution of conflicts and societal challenges. In other words, constructive journalism also represents a break with the norms of Western journalism that emerged in the late nineteenth and early twentieth centuries (e.g. Conboy 2004; Hampton 2008).

In addition, Haagerup's key criteria, outlining the contours of constructive journalism, put strong emphasis on a changed relation between journalism and the audience. In the traditional and almost universal normative understandings of Western journalism (e.g. Hanitzsch and Mellado 2011), journalism has, as indicated, mainly been described as an institution engaged in informing and alerting citizens, the public, on what is going on in the world. The principles of constructive journalism, as formulated here, suggest a broader conception of the audience because journalism should be more engaged in empowering the audience and more concerned with the well-being of the audience. These formulations imply understandings of audiences associated with soft news and service journalism. Therefore, we argue that constructive journalism from a practice per- spective combines elements traditionally associated with hard news, with elements tra- ditionally associated with soft news and service journalism.

\section{Constructive Journalism-From a Research Perspective}

In the research literature, there have been very few attempts to define constructive journalism because research in the field is theoretically as well as empirically a newer phenomenon.

One important contribution, however, is McIntyre's work (McIntyre 2015, 2017; McIn- tyre and Gyldensted 2017). One of her main focus areas has been to investigate the effects of constructive journalism on audiences. She demonstrates that individuals exposed to journalistic pieces with more positive angles and solutions have stronger intentions to engage in solution-oriented behavior than people exposed to more negative framing in news stories (McIntyre 2015, IV). She argues that constructive journalism is "an emerging form of journalism that involves applying positive psychology techniques to news work in an effort to create more productive, engaging stories while holding true to journalism's core functions" (McIntyre 2015, 7). Thus, positive psychology is a key component in her defi- nition and work. McIntyre argues that constructive journalism is rooted in older forms of journalism, such as community journalism, civic journalism and citizen journalism $(2015,10)$, but for journalism to be considered constructive journalism, it requires "a specific positive psychology technique (that) must be applied in the news content" $(2015,27)$. McIntyre also points to positive journalism and solutions journalism as related journalistic approaches that employ techniques from positive psychology. Echoing the practice- based literature, this approach thus suggests a break away from the distanced/neutral as well as adversarial approach in journalists' reporting of world events and crises, consciously taking on a more active, positive and productive role. Based on an experimental design involving 110 US undergraduate students, McIntyre (2017, 14) shows that "individuals felt significantly less negative when they were presented with an effective solution to the problem, signaling that a solution-based story might mitigate some harmful effects of negative news stories, such as compassion fatigue". In line with these studies, and also based on an experimental audience study with 710 participants, Gyldensted (2011) demonstrated that negative news got negative feedback from the audience, while positive news got positive feedback. However, she has also pointed to an important difference between positive journalism and constructive journalism, as positive journalism often lacks societal significance, while constructive journalism "adheres to one or more of journal- ism's core functions, i.e.: Serving as a watchdog, alerting the public of potential threats, dis- seminating important information in order to create an informed electorate" (Gyldensted 2015, 13).

Bro $(2012,137)$ has, in more general terms, argued that constructive news is charac- terized by its specific approach to stories and that "constructive" is to be understood as an add-on to existing news values, such as those outlined by Galtung and Ruge (1965) or Tuchman (1978). Though the 
news value concept itself is "slippery" (O'Neill and Harcup 2009), study programs, for example in Denmark, have long taught students five key news values - Timeliness, Relevance, Identification, Conflict and Sensation. These news values resonate with the international literature, as Harcup and O'Neill $(2017,1482)$ recently summarized 15 news values, among which exclusivity, bad news and conflict rank top three, while good news rank number 14. Journalists use these values in their professional practice as part of their journalistic gut feeling or doxa, and these doxic news values tend to favor hard news (Schultz 2007). Bro (2012) argues that constructive news represents an alternative way of producing news by either looking for positive news in the world - for example states succeeding in solving issues of unemployment — or by actively taking part in other types of problem solving. Journalists accomplish this by performing "action journalism", yet another type of journalism, which has a quite long history and resembles early forms of journalism of a more "subjective" and opinion based nature (e.g. Schudson 2001; Steensen 2011). In his analysis of early examples of constructive journalism from the beginning of the twentieth century, Bro argues that one of the founding fathers of Danish professional journalism, Henrik Cavling, in fact practiced an early kind of constructive news or "action journalism", when he played an active role in developing day-care institutions $(2012,133)$. However, this active role was gradually overtaken by the norms of objectivity, autonomy and detachment (e.g. Deuze 2005), as journalism became increasingly professio- nalized. As the welfare society developed, the state was increasingly commissioned with the task of providing solutions, while the idea of journalists as active and solution-oriented agents was abandoned. In that sense, Bro (2012) argues that constructive news resonates well with early developments of journalism, but also that these ways of producing journal- ism were replaced with a more objective, conflictual and sensation-based approach, that is approaches key to the modern ideology of Western journalism, as suggested by the news values and norms listed above.

Last, we will point to a thesis on constructive journalism, using content analyses and interviews with seven centrally placed leaders at Danish news institutions as empirical data (Jacobsen 2010). As this study was conducted only a few years after the launch of the concept, it represents pioneer research in the field. The interviewed editors voiced both skeptical and positive views on constructive journalism. Repeating some of the key points mentioned above, the critical voices argued that society needs neutral, autonomous journalists and an investigative and critical press. The more positive voices made the argu- ment that the public does not take the news media seriously anymore because reporting is too focused on conflicts and negativity. Similar to the practice-based and theoretical defi- nitions, Jacobsen (2010) concluded that constructive journalism is characterized by its orientation towards solutions to specific problems but also that journalists are not directly involved in developing such solutions, but engage citizens, politicians and experts in these processes (Jacobsen 2010, 94). Finally, he argues that constructive news is related to problemoriented journalism, positive journalism and "news you can use", of which the latter is often associated with lifestyle and consumer journalism (Jacobsen 2010, 98), i.e. types of journalism often grouped under the service journalism umbrella term.

No matter how limited the literature may be, the research on constructive journalism provides historical perspectives that implicitly suggest that the approaches said to be con- stitutive of constructive journalism are not all new. It also provides analyses of the (positive) effects of constructive news on audiences, presents practitioners' mixed views on the phenomena and indicates that constructive news relates to different subfields of journal- ism. In the remaining parts of the article, we elaborate on this last perspective by pointing to the epistemological similarities between constructive journalism and soft news in general and service journalism more specifically.

Soft News and Service Journalism—Well-known Ways of Grasping Constructive Journalism?

To understand how constructive journalism echoes approaches known from soft news, service journalism and their journalistic subfields, we need to grasp the main con- tours of these types of 
journalism. Significant elements include the mode of addressing audiences as individuals, the positioning of the journalist as engaged and the more positive (than negative) approach to stories and events.

\section{Hard News/Soft News}

"Soft news" is an umbrella term used about types of journalism that are often viewed as counterpoints to hard news. This hard news/soft news distinction, or dichotomy, is key in the professional boundary work of journalism (Sjøvaag 2015). Since most scholars and prac- titioners view hard news as the epitome of Western journalism ideology, soft news is often criticized for having invaded hard news as a consequence of the commercialization and tabloidization of journalism (e.g. Patterson 2000; Plasser 2005). Reinemann et al. (2011) argue that a main challenge of the research in the field is scholars' quite imprecise demar- cation and use of the hard news/soft news terms. Yet, there are some overall distinctions with regard to topicality (for example whether a story is of public relevance or mainly of relevance to the individual), timeliness (for example if the story needs immediate publi- cation or can be distributed anytime), style or genre (for example if the story is presented objectively or involves analytical reflection, or even subjectivity) and, most importantly in this context, audience address (are audiences addressed as collective, i.e. citizens, or as indi- viduals) (see, for example, Boczkowski 2009; Reinemann et al. 2011; Sjøvaag 2015). These hard news/soft news distinctions may, as they are presented here in brief, come across as crude, but they nonetheless help point out how constructive journalism straddles oppo- sites: It takes its point of departure in hard news, as indicated by the review of the practice- based and academic literature, while simultaneously mirroring elements from soft news more generally and service journalism in particular, when it comes to timeliness, style/ genre and audience address. Thus, constructive journalism in its own distinct way seems to combine elements characteristic of hard news with elements characteristic of soft news and, more specifically, of service journalism.

\section{Service Journalism and Its Subfields: Cultural Journalism, Lifestyle Journalism and Consumer Journalism}

Service journalism has been part of Western journalism since the early twentieth century and especially following the World War II (Eide 1998; Eide and Knight 1999; Hjarvard 1995; From 2007). However, it was not defined in research until the 1980s and 1990s. The rise of service journalism, as presented by Eide and Knight in their seminal article from 1999, was seen as a response to broader changes in culture and society in the post-World War II period, but also to changes at the level of media institutions.

First, service journalism was seen as an outcome of the increasing complexity and reflexivity of modernity, or as a "reaction in part to growing skepticism, hostility and resist- ance towards dependency on established forms of professional expertise, and the demand for greater individual autonomy" (Eide and Knight 1999, 526). By means of service journal- ism, news media and journalism took on the role of providing expertise and advice on social and moral issues of everyday life, since the established institutions often associated with such tasks were losing ground, e.g. academia and schools. Associated societal changes, such as individualization, consumerism and promotional culture, were also seen as driving forces of service journalism because " $\mathrm{t}]$ he proactive, individualized focus of risk-oriented advice fits particularly well with promotional logic given its emphasis on potentialization, striving and self-empowerment" (Eide and Knight 1999, 533). Similarly, service journalism was tasked with "providing life help to the modern human being, who in his/her consumption, career, leisure time and personal development needs guidance for living in a society that is constantly changing" (Hjarvard 1995, 56, translated by the authors, emphasis in the original). 
Second, and relatedly, the rise of service journalism is linked to institutional changes in the media, among others the popularization and tabloidization of journalism. This change also involved new interpretations of public service by media institutions - from a focus on public to a focus on service, "addressing publicly the concerns of private lives" (Eide and Knight 1999, 529). Service journalism in the press represented a new way of tar- geting readers by adopting topics and modes of address previously known mainly from the magazine press (Hjarvard 1995, 56). However, service journalism was also a way for news institutions to appeal to advertisers and thus a means to new commercial collaborations, at a time when increasing competition especially from television necessitated new business models. More specifically, Hjarvard argues that service journalism's "starting point is not outside the newspaper's own domain; it does, for example, not take the political insti- tutions' themes or actors as point of departure, but the newspaper's own readers in their capacity as being private individuals" (Hjarvard 1995, 56, translated by authors).

In this changed society and news media landscape, the boundaries increasingly became blurred between public identities as citizens served by the state and consumers served by the market (Eide and Knight 1999, 536, 539). Eide and Knight added the identity of "client" to the nexus, with professional media advising clients to solve, prevent and act on everyday life problems. Or put differently: the "client" was informed by the news media about his or her rights in an increasingly complex life world, but was also addressed as a reflective subject, actively accepting or rejecting the news media's advice (Eide and Knight 1999, 540). In this way, they linked service journalism to Beck's notion of subpolitics, i.e. politicized actions on everyday issues from a bottom-up rather than top-down perspec- tive, since "[s]ervice journalism is part of the more fluid and permeable political culture that has arisen with the growing complexity and reflexivity of modernity" (Eide and Knight 1999, 546). This suggests that service journalism addresses not only the social and personal pro- blems of individuals but also connects to broader political and economic issues and struc- tures. It also suggests that service journalism represented an alternative to the norms of objectivity, distance and autonomy in journalism (e.g. Deuze 2005). This is also one of the reasons why service journalism is often defined in opposition to hard news.

Similar to soft news, service journalism is often used as an umbrella term for journal- istic subfields, such as cultural journalism, lifestyle journalism and consumer journalism (Hanusch 2012; Kristensen and From 2012), or for "news you can use" (Underwood 2001). These subfields can serve as illustrative examples of how journalism echoes the increasing reflexivity and complexity of modernity and the changed news media landscape, described above. Cultural journalism, for example, serves as an interface or mediator between cultural institutions, industries and consumers in a globalized society character- ized by cultural oversupply. Cultural journalists are gatekeepers who bring audiences' atten- tion to selected cultural topics and goods (Janssen and Verboord 2015) and provide cultural perspective, aesthetic experience and societal reflection on modern life to cultural citizens (Kristensen and From 2012). Furthermore, it is a type of journalism often associated with journalists' personal style or storytelling, blurring the boundaries of news and views (e.g. Chong 2017; Kristensen and From 2015). In line with these definitions, "lifestyle journalism" is, by Hanusch and Hanitzsch, defined as "the journalistic coverage of the expressive values and practices that help create and signify a specific identity within the realm of consump- tion and everyday life" $(2013,947)$. Hanusch (2017) shows that lifestyle journalists see it as their role to be service providers, life coaches, community advisors and inspiring entertai- ners, while Hanusch, Hanitzsch, and Lauerer (2017) emphasize the often very close ties to market interests in lifestyle journalism. Also the literature on "consumer journalism" points to the complex nature of this journalistic subfield because it traverses traditional topical dis- tinctions by covering politics, economy, business as well as consumer goods and lifestyle products by means of investigative journalism techniques and uncritical product presenta- tions on the fringes of branded content (e.g. Sundvor 2008). In this manner, consumer jour- nalism provides useful information, guidance and relaxation to audiences in their capacity of citizens as well as consumers (From 2007). Thus, 
cultural journalism, lifestyle journalism and consumer journalism are related types of journalism which have for long been service- oriented, focusing on the preferences and needs of individualized audiences, and these types of journalism have created a realm or sphere for reflection and mirrored central cul- tural and societal changes.

Service journalism has thus, first, in terms of content, traditionally covered many different but often consumer-related subjects and objects - cars, fashion, food, cultural events - but also more abstract cultural phenomena and politically infused issues, such as wellness, subcultures, psychology, gender, sexuality and human relations (Kristensen and From 2012, 28). Despite some political undertones, such content is not considered key to the normative role of journalism in terms of informing citizens on issues of public significance and scrutinizing those in power. Second, and relatedly, service journalism is seen to guide audiences on matters of choices in everyday life in an increasingly complex society. In this manner, it is characterized by its mode of addressing audiences as individuals more than as members of the public - as consumers more than as citizens. However, service journalism is, as indicated, part of the more fluid and permeable political culture where individual consumption and life choices may indeed be political. While other types of journalism, such as tabloid or entertainment journalism, do not necessarily engage with audiences as mainly citizens either, the mode of address of service journalism appears to be more complex. It suggests that audiences cannot simply be reduced to mere consumers, as the boundaries between conceptions of the consumer and the citizen blur in this type of journalism. Third, the genres of service journalism adhere less to factual news and key questions of "what, where, when, whom", and more to advice, listings, ratings and "news you can use" (Underwood 2001; Eide 2017) with the ambition of guiding the audience and providing useful information. Fourth, service journalism is characterized by the ways in which journalists take on very active roles and engage, implicitly or explicitly, in solving problems in peoples' everyday lives. Eide (2017) has, for example, argued that journalists doing service journalism demonstrate participatory actions: "Through the format of service journalism, journalists express that they are at the service of their audience. They stress that they are ready to contribute to solving everyday problems and providing the pleasures of consumption" (Eide 2017, 199). Similarly, Hanitzsch, Löffelholz, and Weaver $(2005,109)$ argue that service journalism represents a shift in the social function of news by signifying a general journalistic move "away from merely disseminating information to selecting what is relevant" at a time of increasing information overload. That is, service journalism represents the idea that journalism should empower the individual and "equip" the audience to navigate a complex world.

To exemplify service journalism, Usher (2012) analyses a section of The New York Times called "Your Money". Similar to Haagerup (2015), she thus points to content focusing on personal finance, but whereas he analyzed this type of stories to illustrate constructive journalism, Usher uses them as an example of service journalism. The section "Your Money" has a long history, running from 1913, and covering private investments from the late 1970s. Following Usher's analysis of this newspaper section, service journalism serves as a

distinct form of journalism charged with helping people make decisions. They [the journalists] act as agents for people who would not ordinarily have access to people like executives. They can be the first testers for products, or provide information that ordinary people do not have time to research on their own. $(2012,119)$

Usher makes the argument that service journalism in this context facilitates a community and represents a changed social function of journalism from positioning the journalist as a neutral reporter to positioning the journalist as a participant in communities and in peoples' private lives.

In summary, research engaged in studying the rise of service journalism is closely linked to, on the one hand, increasing scholarly attention to the ways in which news may engage people rather than 
being exclusive and elitist. On the other hand, service journalism has also been linked to broader scholarly discussions of the decline of journalism because service journalism has been viewed as a result of commercialization, tabloidization and an increasing focus on entertainment (Eide 2017). Constructive journalism seems to apply approaches similar to those of service journalism, since both service journalism and constructive journalism exemplify broader transformations towards more fluid boundaries between previous dichotomies, such as hard/soft news, elite/tabloid, information/ entertainment, fact/opinion or objectivity/subjectivity (Steensen 2017).

\section{Conclusion: Constructive Journalism and Service Journalism-Similarities and Differences}

The main argument in this article has been for constructive journalism scholars to look to the historical paths of service journalism and its subfields, such as cultural journal- ism and lifestyle journalism, to understand the trajectories of this seemingly new approach in journalism practice. However, while service journalism emerged in the increasingly commercialized and globalized media landscape of the post-World War II period, and especially the 1980s and 1990s, constructive journalism has emerged in the digital media landscape of the 2010s. These historical contexts provide particular circumstances for media institutions and journalism, which should, of course, not be neglected.

While service journalism was, at least in a Nordic context, a solution to an increasingly competitive and commercialized media market, the "constructive movement" is an addition to journalism in a digitalized society, where the authority and gatekeeping role of professional journalism is highly contested and journalism is said to be in crisis. In the digital media landscape, journalists are, according to some, reduced to gatewatchers (Bruns 2008), when politicians and ordinary people can communicate on blogs, Facebook and Twitter without the interference of professional journalists and thus bypass institutionalized news media (Haagerup 2015, 113ff; Ryfe 2012). Furthermore, in the age of "fake news" or "post-factuality", the truth and objectivity paradigms of professional journalism are more challenged than ever, as the strategic ritual of objectivity has lost its value "as a guarantee of quality in the provision of information" (McNair 2017, 1323). While service journalism was seen as a response to other societal institutions' loss of authority, with journalism taking on new expert and advisory roles to help citizen-consumer clients, constructive journalism can be seen as a response to the news institution's and professional journalism's own loss of authority. In such a changed media landscape, constructive journalism may revitalize journalism's role in and obligation to society by more explicitly taking on a solution-oriented and positively inclined service role with regard to both public and private life matters of audiences. However, the critical voices opting against constructive journalism point to the challenges of journalism applying such a normative and positive approach. By potentially neglecting some of the grim aspects of reality and by distancing journalism from key values such as objectivity, autonomy, a critical approach, and so on, journalism could lose credibility and appear even less authoritative.

When comparing the definitions of constructive journalism and service journalism, they seem to have at least two things in common: (1) a changed mode of address and (2) a changed understanding of the function or role of news/journalism. Both constructive journalism and service journalism assume an active, engaged reader, looking for advice and orientation in an increasingly "chaotic" world where people need guidance — in a broad sense, i.e. the mindset and the approach of constructive journalism and service journalism seem to overlap, as both types exemplify that the role of journalism and its mode of address are being reconfigured. However, a main (historical) difference between the two is that service journalism has, predominantly, been associated with soft news and subfields like cultural, lifestyle and consumer journalism, and thus the individual and everyday life. More- over, service journalism has often been associated with very close ties to consumption and the market (e.g. Hanusch, Hanitzsch, and Lauerer 2017; Kristensen and From 2012). Constructive journalism has, on the contrary, been associated with hard news and thus the 
political public sphere, and it has been developed not in the popular or tabloid press but in (Danish) public service media. Many of the examples highlighted as constructive journalism in the practicebased literature are, for instance, related to topics most often perceived to be of broader societal relevance. We argue that constructive journalism, by means of its positive and solution-oriented approach, should be seen as an approach that combines elements often associated with service journalism, not least the mode of address and the considerations of relevance, with social topics often associated with hard news. Thus, it exemplifies how the boundaries between soft and hard news often blur in journalism practice. The stories about financial issues of private individuals referred to in this article as examples of both constructive journalism and service journalism illustrate this. By providing solutions to individual and social problems, both service journalism and constructive journalism seek to regain public trust in news and reclaim journalism's authority in society. Regaining public trust in the news seems to be needed: Reuters Institute has shown that trust in the news varies greatly across the world-from high trust in Finland, where 62 percent trust the news, to only 23 percent trusting the news in South Korea and Greece (Newman et al. 2017, 10). Research has suggested that constructive news strengthens the well-being and conceived empowerment of people (McIntyre 2015), but whether constructive news by means of its more service-oriented and positive approach may also strengthen public trust in the news remains an open question.

This points to several future research paths for journalism scholarship on softer forms of journalism: One important theoretical task, commenced but far from fully developed in this article, is the outline of the histories and conceptual contours, distinctions and overlaps of the many types of journalism of a service-oriented or constructive nature. Another important empirical task is to provide more systematic analyses of how newsrooms, editors and journalists work with such softer types of journalism, the actual types of journalism these practices produce and how these practices and their outcomes contribute to reconfiguring key values and boundaries of the profession. A third task is to study the implications of this reconfiguration from a user perspective, a research path commenced by the work of McIntyre $(2015,2017)$ in the field of constructive and solutions journalism.

\section{DISCLOSURE STATEMENT}

No potential conflict of interest was reported by the authors.

\section{FUNDING}

This work was supported by Independent Research Fund Denmark [grant DFF-4180- 00082].

\section{NOTES}

1. In brief, the social function of journalism refers to the idea that journalists' perceptions of their roles in society, and the role of journalism as such, will shape the way they report news and, thus, the way they perform their role. The debates about the role of service journalists link to broader scholarly discussions on the changed role of journalists (e.g. Hell- mueller and Mellado 2015). Studies have pointed to journalistic roles, such as "populist disseminators", "detached watchdogs", "critical change agents" and "opportunist facilitators" (e.g. Hanitzsch 2011), while Hanitzsch and Vos (2016) have outlined no less than 18 different roles for journalists in the domain of political life.

2. From 2016, Ulrik Haagerup has been director of Constructive Institute, an independent organization, established with the aim of helping "journalists and news organisations to apply constructive reporting in their daily work through providing access to an inspiring best practices portal, a world-class fellowship programme, relevant training curricula, and 
initiating rigorous independent academic research" (https://constructiveinstitute. org, accessed March 11, 2018). A similar initiative is the London-based Constructive Journalism Project which, also building on a positive approach to the production of journal- ism, "aims to innovate and strengthen journalism by developing methods for journalists to bring more positive and solution-focused elements into conventional reporting" (constructivejournalism.org, accessed March 11, 2018). A third example of an institutional framework for the development of constructive journalism is the Open Eyes Institute in Amsterdam, focusing on constructive journalism, investigative journalism and data-driven journalism (http://www.openeyesinstitute.org/home, accessed March 11, 2018) and cofounded by Cathrine Gyldensted, Geesje van Haren and Paul van der Cingel.

\section{REFERENCES}

Andreassen, Andreas Marckmann. 2010. "Mediechefer Kritiserer Ideen om 'Konstruktive Nyheder'. [Media Bosses Criticize the Notion of 'Constructive News']”. Journalisten, November 1.

Benesch, Susan. 1998. "The Rise of Solutions Journalism.” Columbia Journalism Review 36 (6): 36.

Bläsi, Burkhard. 2004. "Peace Journalism and the News Production Process." Conflict \& Communication Online 3 (1/2): 1-12.

Boczkowski, Pablo. 2009. "Rethinking Hard and Soft News Production: From Common Ground to Divergent Paths.” Journal of Communication 59 (1): 98-116. doi:10.1111/j.14602466.2008.01406.x.

Bro, Peter. 2012. "Historien om den nyttige nyhedsformidling. ['The Story About Useful News.'].'In Et opgør med pressens negative verdenssyn. En konstruktiv nyhed [Settling with the Negative Worldview of the Press], edited by Ulrik Haager, 129-143. Aarhus: Ajour.

Bruns, Axel. 2008. Blogs, Wikipedia, Second Life, and Beyond: From Production to Produsage. New York: Peter Lang.

Chong, Phillipa. 2017. "Valuing Subjectivity in Journalism: Bias, Emotions, and Self-interest as Tools in Arts Reporting." Journalism. Advance online publication. doi:10.1177/1464884917722453.

Conboy, Martin. 2004. Journalism: A Critical History. London: Sage.

Deuze, Mark. 2005. "What is Journalism? Professional Identity and Ideology of Journalists Reconsidered.” Journalism 6 (4): 442-464. doi:10.1177/1464884905056815.

Eide, Martin. 1992. Den fjerde servicemakt [The Fourth Service Estate]. Bergen: Institutt for massekommunikasjon.

Eide, Martin. 1998. "Etterkrigsavisen og hjemmefronten [The Post-War Newspaper and the Home Front]." Mediekultur 14 (8): 15-22. 
Eide, Martin. 2017. "The Culture of Service Journalism.” In Cultural Journalism in the Nordic Countries, edited by Nete Nørgaard Kristensen and Kristina Riegert, 195-204. Göteborg:

Nordicom.

Eide, Martin, and Graham Knight. 1999. "Public/Private: Service Journalism and the Problems of Everyday Life.” European Journal of Communication 14 (4): 525-547.

From, Unni. 2007. "Forbruger og Livsstilsjournalistik [Consumer and Lifestyle Journalism]." Mediekultur 27: 35-45.

Galtung, Johan, and Mari Holmboe Ruge. 1965. "The Structure of Foreign News. The Presentation of the Congo, Cuba and Cyprus Crises in Four Norwegian Newspapers." Journal of Peace Research 2: 64-91. doi:10.1177/002234336500200104.

Giddens, Anthony. 1991. Modernity and Self-Identity. Stanford, CA: Stanford University Press.

Gyldensted, Cathrine. 2011. Innovating News Journalism Through Positive Psychology. Philadelphia: University of Pennsylvania.

Gyldensted, Cathrine. 2015. From Mirrors to Movers: Five Elements of Positive Psychology in Constructive Journalism. Lexington, KY: Ggroup Publishing.

Gyldensted, Cathrine, and Malene Bjerre. 2014. Håndbog i Konstruktiv Journalistik [Handbook in Constructive Journalism]. Aarhus: Ajour.

Haagerup, Ulrik. 2008. “Konstruktive nyheder [Constructive new].” Politiken, December 6.

Haagerup, Ulrik, ed. 2012. Et opgør med pressens negative verdenssyn. En konstruktiv nyhed [Settling with the Negative Worldview of the Press]. Aarhus: Ajour.

Haagerup, Ulrik. 2015. Constructive News. Hanoi: Innovatio.

Haagerup, Ulrik. 2017. Constructive News. Aarhus: Aarhus University Press.

Hampton, Mark. 2008. “The 'Objectivity' Ideal and Its Limitations in 20th Century British Journalism.” Journalism Studies 9 (4): 477-493. doi:10.1080/14616700802113060.

Hanitzsch, Thomas. 2011. "Populist Disseminators, Detached Watchdogs, Critical Change Agents and Opportunist Facilitators: Professional Milieus, the Journalistic Field and Autonomy in 18 Countries." International Communication Gazette 73 (6): 477-494.

doi:10.1177/1748048511412279.

Hanitzsch, Thomas, Martin Löffelholz, and David H. Weaver. 2005. "Building a Home for the Study of Journalism: ICA Creates a Journalism Studies Interest Group.” Journalism 6 (1): 107-115. doi:10.1177/1464884905048955.

Hanitzsch, Thomas, and Claudia Mellado. 2011. "What Shapes the News Around the World? How Journalists in 18 Countries Perceive Influences on Their Work." The International Journal of Press/Politics 16 (3): 404-426. doi:10.1177/1940161211407334. 
Hanitzsch, Thomas, and Tim Vos. 2016. "Journalism Beyond Democracy: A New Look into Journalistic Roles in Political and Everyday Life.” Journalism. Advance online publication. doi:10. $1177 / 1464884916673386$.

Hanusch, Folker. 2012. "Broadening the Focus: The Case for Lifestyle Journalism as a Field of Scholarly Inquiry.” Journalism Practice 6 (1): 2-11. doi:10.1080/17512786.2011.622895.

Hanusch, Folker. 2017. "Journalistic Roles and Everyday Life: An Empirical Account of Lifestyle Journalists' Professional Views.” Journalism Studies. Advance online publication. doi:10. 1080/1461670X.2017.1370977.

Hanusch, Folker, and Thomas Hanitzsch. 2013. "Mediating Orientation and Self-Expression in the World of Consumption: Australian and German Lifestyle Journalists' Professional Views." Media, Culture \& Society 35 (8): 943-959. doi:10.1177/0163443713501931.

Hanusch, Folker, Thomas Hanitzsch, and Corinna Lauerer. 2017. “How Much Love Are You Going to Give This Brand?' Lifestyle Journalists on Commercial Influences in Their Work." Journalism 18 (2): 141-158. doi:10.1177/1464884915608818.

Harcup, Tony, and Deirdre O’Neill. 2017. "What Is News? News Values Revisited (Again)." Journalism Studies 18 (12): 1470-1488. doi:10.1080/1461670X.2016.1150193.

Hellmueller, Lea, and Claudia Mellado. 2015. "Professional Roles and News Construction: A Media Sociology Conceptualization of Journalists' Role Conception and Performance." Communication \& Society 28 (3): 1-12. doi:10.15581/003.28.3.1-11.

Hjarvard, Stig. 1995. Nyhedsmediernes rolle i det politiske demokrati [The Role of the News Media in Political Democracy]. København: Rapport Udgivet af Medieudvalget, Statsministeriet.

Jacobsen, Fred. 2010. "Konstruktive nyheder: præcisering og placering [Constructive News: Precision and Position].” MA diss. University of Southern Denmark.

Janssen, Susanne, and Marc Verboord. 2015. "Cultural Mediators and Gatekeepers.” In International Encyclopedia of the Social \& Behavioral Sciences, edited by James Wright, 440- 446. 2nd ed. Vol. 5. Oxford: Elsevier.

Kempf, Wilhelm. 2007. "Peace Journalism: A Tightrope Walk Between Advocacy Journalism and Constructive Conflict Coverage.” Conflict \& Communication Online 6 (2): 1-9.

Kristensen, Nete Nørgaard, and Unni From. 2012. "Lifestyle Journalism: Blurring Boundaries." Journalism Practice 6 (1): 26-41. doi:10.1080/17512786.2011.622898.

Kristensen, Nete Nørgaard, and Unni From. 2015. "Cultural Journalism and Cultural Critique in a Changing Media Landscape.” Journalism Practice 9 (6): 760-772. doi:10.1080/17512786. 2015.1051357.

McIntyre, Karen. 2015. "Constructive Journalism: The Effects of Positive Emotions and Solution Information in News Stories.” PhD diss. University of North Carolina at Chapel Hill.

McIntyre, Karen. 2017. "Solutions Journalism. The Effects of Including Solution in Formation in News Stories About Social Problems.” Journalism Practice. Advance online publication. 
McIntyre, Karen, and Cathrine Gyldensted. 2017. "Constructive Journalism: An Introduction and Practical Guide for Applying Positive Psychology Techniques to News Production." The Journal of Media Innovations 4 (2): 20-34.

McNair, Brian. 2017. “After Objectivity.” Journalism Studies 18 (10): 1318-1333. doi:10.1080/ 1461670X.2017.1347893.

Newman, Nic, Fletcher Richard, Kalogeropoulos Antonis, Levy David A. L., and Nielsen Rasmus Kleis. 2017. Reuters Institute Digital News Report 2017. Oxford: Reuters Institute for the Study of Journalism.

O’Neill, Deirdre, and Tony Harcup. 2009. "News Values and Selectivity." In The Handbook of Journalism Studies, edited by Karin Wahl-Jorgensen and Thomas Hanitzsch, 161-174. New York: Routledge.

Patterson, Thomas E. 2000. Doing Well and Doing Good: How Soft News Are Shrinking the News Audience and Weakening Democracy. Cambridge, MA: Harvard University Press.

Plasser, Fritz. 2005. "From Hard to Soft News Standards? How Political Journalists in Different Media Systems Evaluate the Shifting Quality of News." Press/Politics 10 (2): 47-68.

Reinemann, Carsten, James Stanyer, Sebastian Scherr, and Guido Legnante. 2011. "Hard and Soft News: A Review of Concepts, Operationalizations and Key Findings." Journalism 13 (2): 221-239.

Ryfe, David. 2012. Can Journalism Survive?: An Inside Look at American Newsrooms. Cambridge: Polity Press.

Schudson, Michael. 2001. "The Objectivity Norm in American Journalism.” Journalism, 2 (2): 149_ 170. doi:10.1177/146488490100200201.

Schultz, Ida. 2007. “The Journalistic Gut Feeling.” Journalism Practice 1 (2): 190-207. doi:10.1080/17512780701275507.

Sjøvaag, Helle. 2015. "Hard News/Soft News: The Hierarchy of Genres and the Boundaries of the Profession." In Boundaries of Journalism: Professionalism, Practices and Participation, edited by Matt Carlson and Seth Lewis, 101-118. New York: Routlegde.

Steensen, Steen. 2011. "The Featurization of Journalism. What Feature Journalism Is and How it Transforms as Genre.” Nordicom Review 32 (2): 49-61.

Steensen, Steen. 2017. “Subjectivity as a Journalistic Ideal.” Paper presented at ICA 2017.

Strömbäck, Jesper. 2005. "In Search of a Standard: Four Models of Democracy and Their Normative Implications for Journalism." Journalism Studies 6 (3): 331-345.

Sundvor, Eigil. 2008. Forbrukarjournalistikk [Consumer Journalism]. Kristiansand: IJ.forlaget.

Tuchman, Gaye. 1978. Making News: A Study in the Construction of Reality. New York: Free Press. Underwood, Doug. 2001. "Reporting and the Push for Market-Oriented Journalism: Media 
Organizations as Businesses." In Mediated Politics. Communication in the Future Democracy, edited by Lance Bennett and Robert Entman, 99-117. Cambridge: Cambridge University Press.

Usher, Nikki. 2012. "Service Journalism as Community Experience.” Journalism Practice 6 (1): 107- 121. doi:10.1080/17512786.2011.628782.

Unni From, Aarhus University, ARTS, Aarhus, Denmark. E-mail: imvuf@cc.au.dk Nete Nørgaard Kristensen (author to whom correspondence should be addressed),

Department of Media, Cognition and Communication, University of Copenhagen, Copenhagen, Denmark. E-mail: netenk@hum.ku.dk 